\title{
The 'Green' Premium in Israel: Measuring the Effects of Environmental Certification on Housing Prices
}

\author{
Elise Machline ${ }^{1}$, David Pearlmutter ${ }^{1} \&$ Moshe Schwartz $^{1}$ \\ ${ }^{1}$ Blaustein Institutes for Desert Research, Ben Gurion University, Israel \\ Correspondence: Elise Machline, Blaustein Institutes for Desert Research, Ben Gurion University, Israel. E-mail: \\ elise.machline@gmail.com
}

Received: July 4, $2018 \quad$ Accepted: August 9, $2018 \quad$ Online Published: September 28, 2018

doi:10.5539/jsd.v11n5p162 URL: https://doi.org/10.5539/jsd.v11n5p162

\begin{abstract}
'Green' building initiatives have led to the emergence of market-based policy approaches in a number of countries. Many of these have taken the form of environmental certification for buildings. A number of studies have examined the additional construction costs involved in achieving 'green' certification, and these studies suggest that they are relatively low, around $2 \%$ on average. Evidence is accumulating, however, that the "green premium" - or the extra cost that homebuyers pay to purchase a property in a certified green building - is systematically higher than this.

This study aims to identify the nature and scale of the "green premium" in Israel, based on a novel comparative calculation method developed to examine how much 'green' building certification raises an apartment's price. We also examine how economically profitable it is to purchase a 'green' apartment for the homebuyer and for the Israeli economy overall. Finally, through a case study in Tel Aviv, we shed light on how the implementation of environmentally certified housing may lead to gentrification.
\end{abstract}

\section{Introduction}

Numerous policy instruments have been developed worldwide to reduce the energy demand and overall environmental impact of buildings and these efforts have increasingly come under the banner of "green building". Green building can be defined as: "The practice of creating structures and using processes that are environmentally responsible and resource-efficient throughout a building's life-cycle, from a building's site planning to design, construction, operation, maintenance, renovation and deconstruction" (EPA, 2007).

Growing out of the conceptual framework of sustainable development, which attempts to reconcile long-term environmental concerns with short-term socio-economic realities, green building initiatives have led to the emergence of market-based policy approaches in a number of countries. Many of these have taken the form of voluntary environmental certification systems for buildings, such as Green Star (Australia), LEED (United States, Leadership in Energy and Environmental Design), Energy Star (United States), and BREEAM (United Kingdom, Building Research Establishment Environmental Assessment Method). In Israel, a voluntary standard to certify buildings with "reduced environmental impact" - IS 5281 - was established in 2005 and further extended in 2011 and 2016, but green building has remained marginal (Israeli Ministry of Environment Protection, 2016). In 2008, eighteen of the largest cities in Israel joined the International Council for Local Environmental Initiatives' (ICLEI) Cities for Climate Protection Program (CCP), and signed the Forum 15 Convention, committing them to reduce their Greenhouse Gas (GHG) emissions to 20\% below their levels in the year 2000. In June 2013 those cities decided to adopt the green building standard as mandatory, to be phased in gradually over a period of several years.

Israel joined the OECD in 2011 and has thus been expected to comply with the Kyoto Protocol and Agenda 21, which set targets for greenhouse gas (GHG) emissions mitigation. Such mitigation goals must address buildings (residential, office and retail), which account for $65 \%$ of Israel's electricity consumption. Since air conditioning and lighting currently represent $33 \%$ of Israel's CO2 emissions, a share expected to increase to $50 \%$ due to rising standards of living, 'green' building has an especially important potential for GHG emissions abatement (Gabay et al., 2014).

With momentum building at the national level for an expansion of green building in practice, we might consider the economic and social implications of this "new" trend - especially in light of the acute shortage of affordable 
housing that Israel has faced in recent years. A number of studies have examined the additional construction costs involved in achieving green certification (see, Kats 2003; Berry 2007), and these studies suggest that they are relatively low, around $2 \%$ on average. Evidence is accumulating, however, that the "green premium" - or the extra cost that homebuyers pay to purchase a property in a certified green building - is systematically higher than this.

In Israel, 'green' building projects have largely targeted the middle and upper classes and are mainly located in large well-to-do municipalities in metropolitan areas like Kfar Saba, Ra'anana, and Herzliya in the Gush Dan Area around Tel Aviv. Thus, the benefits of Sustainable Urban Development have become concentrated in middle class residential areas. To the extent that this perpetuates socio-spatial and socio-economic inequality, as well as ecological vulnerability for the poor and other socially marginal groups, it runs counter to the goals of sustainable development - which include social, as well as economic and environmental dimensions (WCED, 1987).

This study aims to identify the nature and scale of the "green premium" in Israel, based on a novel comparative calculation method developed for the purpose of examining the extent to which implementation of the 'green' building standard raises housing prices. In addition, we examine how economically profitable it is to purchase a 'green' apartment, not only for the homebuyer but also for the Israeli economy overall. Finally, through a case study in Tel Aviv, we shed light on how the implementation of environmentally certified housing may lead to gentrification.

\subsection{Towards Eco-Gentrification}

Gentrification is a process of urban transformation, whereby the existing population of a local community is displaced by a higher income population. According to Clark (2005): "Gentrification is a process involving a change in the population of land-users such that new users are of higher socio-economic status than the previous users, together with an associated change in the built environment through reinvestment in fixed capital." Gentrification has become a global phenomenon with pronounced social impacts and may in fact be pursued by local governments as a strategy for improving their tax base and achieving other perceived benefits.

Gentrifying neighborhoods are typically characterized by upward pressure on housing prices. There may be different effects on renters and homeowners, and varied consequences for different homeowners. The increase in property values may settle at a new high or reflect "unsustainable speculative property price increases" (Atkinson and Bridge, 2005). Often there is a loss of affordable housing, particularly in the rental market, which can be exacerbated by zoning changes that eliminate single-room occupancies or other low-cost alternatives. Thus, the rise in property values can be fortunate for families who owned homes, but devastating to renters, although homeowners may struggle if their incomes cannot keep pace with rising property tax bills and may find themselves compelled to sell their homes (Slater, 2004).

In Israel, at the edges of large cities, older neighborhoods are changing dramatically as well-off professionals move in and raise housing prices. In Tel Aviv, for example, residents of the older southern neighborhoods have seen over the past several years an influx of young people from central and north Tel Aviv who are earning above-average salaries (Marom, 2014). 


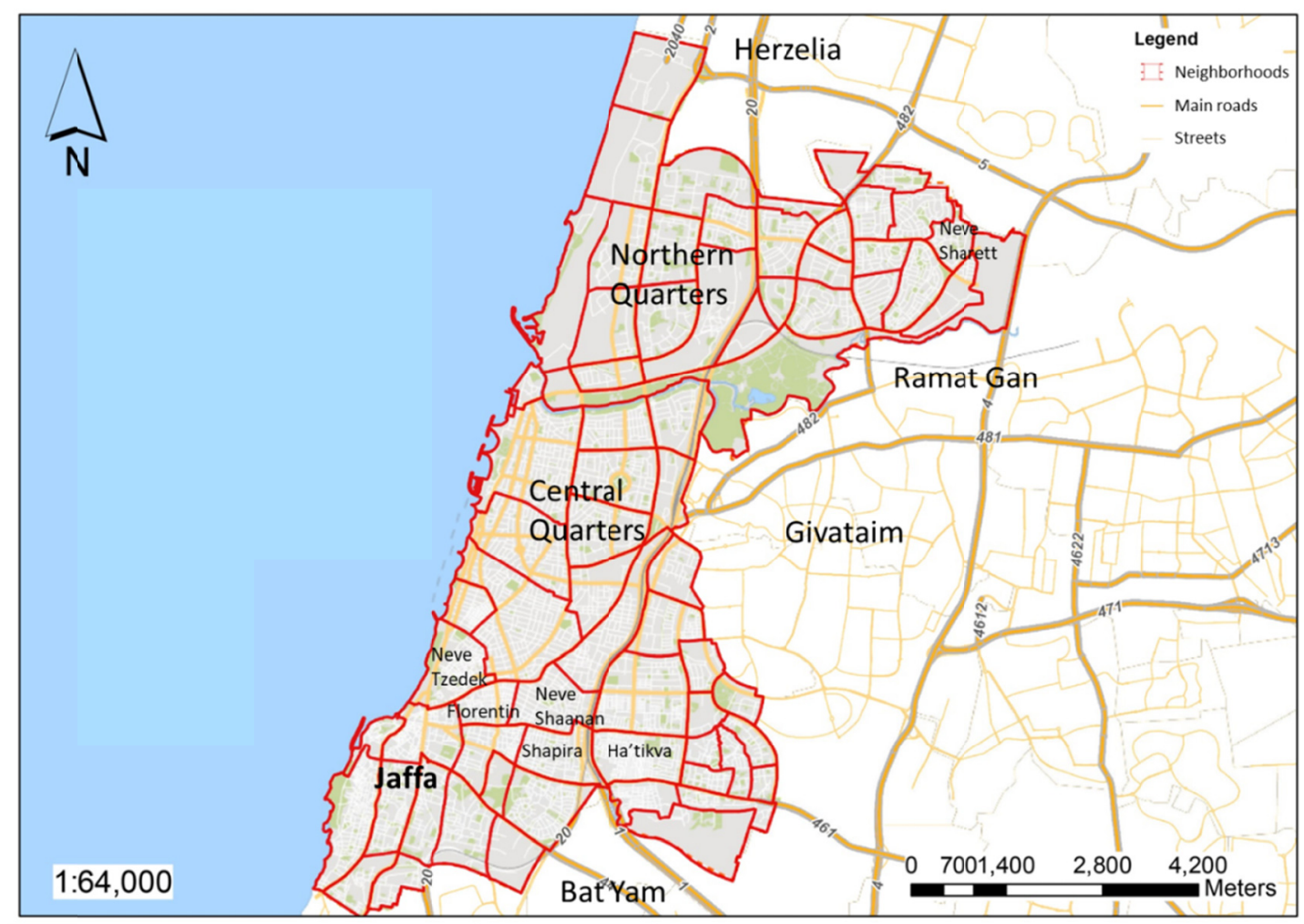

Figure 1. Geographical division of Tel Aviv into quarters

Source: Cohen and Margalit, 2015

This process is occurring in south Tel Aviv neighborhoods such as Shapira, Neveh Sha'anan, and most notably Jaffa, the trendy new location for Tel Aviv's middle class. In less than a decade, housing prices have risen by over $100 \%$ in these neighborhoods, and some have seen major construction and urban renewal projects. The same goes for places such as Neveh Sharett (northeast Tel Aviv), Morasha (Ramat Ha'sharon), Neveh Yisrael and Neveh Amal (both in Herzliya), and many others around the country - nearly all of them in areas with a high housing demand. In Neve Sharett, for example, it was possible to buy a 3-room apartment in 2008 for 400,000 shekels [about $\$ 100,000$ ], while in 2014 it cost 1.5-1.6 million shekels. Along with the improved infrastructures that accompany gentrification, it also has social implications, as veteran residents are priced out of the neighborhood.

In neighborhoods where gentrification has been extensive, "original residents" are hard to find. This is the case in Neveh Tzedek and in nearby Florentin, in south Tel Aviv (Alexander, 2012), as well as in Jerusalem neighborhoods such as Ein Karem, Nachlaot and the German Colony. Before they were transformed into prestigious neighborhoods, all of them included lower-middle-class residents (Gonen, 2015).

Eco-gentrification, or gentrification that accompanies development which is promoted for its environmental benefits, is relatively recent. It is the result of urban policies linked to economic development. Following Checker (2011), we understand such environmental gentrification as:

“...the convergence of urban redevelopment, ecologically-minded initiatives and environmental justice activism in an era of advanced capitalism. Operating under the seemingly a-political rubric of sustainability, environmental gentrification builds on the material and discursive successes of the urban environmental justice movement and appropriates them to serve high-end redevelopment that displaces low income residents."

Such redevelopment can make a neighborhood more attractive and drive up real estate prices and rents, thus displacing local working-class populations while richer homeowners capture the gains in their property assets (Banzhaf and McCormick, 2007). Although sustainability and green urbanism have become central in urban policies, too little analysis has focused on what 'green' is expected to look like. Many visions of the green city seem to have room only for parking spaces, waterfront cafes, and luxury LEED-certified buildings, prompting concern that there is no place in the "sustainable" city for industrial uses and for the working class (Krueger and Agyeman, 2005). 
In Israel, housing is already seen as unaffordable by the 70 percent who can't afford the average price of an old apartment, and the 80 percent who can't afford that of a new one (Milken Institute, 2015). The social protest of 2011 expressed the economic distress of individuals and families in the mainstream of Israeli society - in particular, the distress of young and working families, with high education and employment qualifications, who are overwhelmed by the cost of living, the cost of housing and of the care and education of their small children. It focused explicitly on housing unaffordability. Housing has become the decisive component of the relationship between state and citizen in Israel, capable of drawing hundreds of thousands into the streets to demand social justice (Trajtenberg Report, 2012).

Recent statistical data show that in 2014, an Israeli homebuyer needed the equivalent of 141 months' worth of average wages to purchase a four-room apartment - while in the U.S only 60 were required and in France 90 (OECD, 2016). Considering that less than 0.04 public social housing units exist in Israel per 1000 habitants (Paz and Frankel, 2012), it is worth examining the social and economic implications of 'green' residential construction, scrutinizing the extent to which it raises apartment prices and potentially leads to eco-gentrification.

\subsection{The 'Green' Premium in Israel}

'Green' building may involve additional construction costs, such as those required for better wall insulation or upgraded window glazing. However, the 'green' premium, or the increase in a property's selling price, may reflect more than a passing on of these extra costs to the buyer since it may also include the extra profit to the developer from 'green' construction (Massimo, 2012). Fuerst and McAllister (2011) found that rental prices of regular commercial buildings are lower by $4.1 \%$ on average compared to those complying with LEED and Star Energy standards.

In Israel, economic research about 'green' building has so far only dealt with its costs to builders. Kot and Katz (2013) studied two buildings built according to SI 5281 in Nes Ziona and Netanya, aiming to shed light on the added costs of 'green' components. Their findings indicate an addition of $2.1 \%$ to $4.1 \%$. Gabay et al. (2014) found added costs in the construction of a 'green' office building amounting to between $4.3 \%$ and $11.6 \%$, with over $75 \%$ of this spent on energy saving improvements and only $4 \%$ on certification costs. In this context of these added costs to the builder, we seek to estimate in this study the added costs of 'green' residential buildings that are ultimately borne by the buyer.

\section{Methodology}

\subsection{Green Building and Housing Prices}

The effect of "green" buildings on real estate prices in Israel was assessed by calculating the "green" premium (i.e. the added financial value of a certified green real estate asset, when compared to a similar non-green real estate asset). We compared the market prices of new apartments in certified green buildings with the prices of similar non-certified apartments (located at a maximum distance of 200 meters) sold in the same year. The "green" premium was calculated per square meter of dwelling unit in each municipality and for each year, using a list of 250 residential buildings that have received the SI 5281 certification from the Standards Institute of Israel (SII) (updated 17/07/2016). (Note 1) We included in the sample only multi-family apartment buildings, and ultimately the comparison includes 91 sets of green vs. conventional residential buildings (see list of cities in the results part).

The details of individual buildings were entered in the Israel Tax Authority website, to retrieve the actual sale prices of apartments. These data are based on the declared transaction price and do not include the subsequent cost of upgrading the apartments. To identify the corresponding non-certified buildings for comparison with green buildings in the sample, we used the "GovMap" GIS software (http://www.govmap.gov.il) and compared apartments sold in the same year and built during the same period (i.e. after 2008 - see map and Table in Annex).

The sample size is currently limited in terms of range, number of projects within a city and number of cities, but since the volume of 'green' residential building is expected to grow, future research utilizing a larger database is warranted. This would presumably allow for comparison of the green premia for buildings at higher standard levels, (planned in the Forum 15 cities over the coming years), and for the examination of 'green' premium changes over an extended period of time.

\subsection{Case Study}

Case studies are appropriate when a study focuses on a current topic, the researcher has little control over events and we ask how or why a phenomenon has happened (Yin, 2009). The case study method is used in ethnography, surveys, quantitative modelling etc. (Yin, 2011), and values the use of multiple sources of evidence to foster reliability and improve understanding. Case studies can be used to test theories or use theory to deepen our understanding (de Vaus, 2001), as we have tried to do in the present study. As a case study, we have picked a Tel 
Aviv neighborhood, Neve Sharett, and looked at the impacts of 'green' building on the local residents.

As background, we collected information on the key policy tools designed to promote green building. We examined the application of these tools through analysis of documents, including professional policy reports, central and local government action plans, professional NGO reports, statements of opinion, newspaper articles, municipality meeting protocols, and academic studies. In addition, we looked at how contractors and municipalities market green building projects.

Interviews were conducted with key figures, selected according to the positions they hold in the field (Scott, 1991) as follows:

- Standards Institute of Israel: Head of the 'green' building unit

- Head of the Tel Aviv municipality planning unit

- Tel Aviv municipality 'green' building consulting firm

-Tel Aviv municipality social worker

-Neve Sharett resident's Union

- Representative of Amidar (social housing compagnie) Residents' Association in Neve Sharett

-Tel Aviv municipality, engineering unit, official in charge of Neve Sharett

Finally, a survey was conducted in Neve Sharett to examine the extent of population displacement following the 'greening' of the neighborhood. All of the current apartment owners (154) answered the survey.

\section{Results}

\subsection{The 'Green' Premiun}

According to the calculation method described above, the average 'green' premium was estimated as a percent increase for a number of urban localities across Israel, with the results summarized in Figure 2 and Table 3. (Detailed results for the period 2009-2015 in the various localities can be found in the Appendices).

Table 1 . Number of housing units by city, in certified and non-certified buildings

\begin{tabular}{lll}
\hline City & IS 5281 certified buildings & Non-certified buildings \\
& Number of units & Number of units \\
\hline Be'er Yaakov & 174 & 134 \\
Givataim & 39 & 31 \\
Hod Ha'sharon & 57 & 28 \\
Hedera & 19 & 14 \\
Holon & 41 & 41 \\
Jerusalem & 58 & 38 \\
Pardes Hana-Karkur & 29 & 78 \\
Naharia & 15 & 18 \\
Netanya & 92 & 93 \\
Zur Yizhak & 95 & 179 \\
Kadima Zoran & 7 & 61 \\
Kiriat Ono & 140 & 42 \\
Rehovot & 34 & 33 \\
Ramla & 100 & 129 \\
Ra'anana & 14 & 16 \\
Afula & 41 & 41 \\
Total & 955 & 976 \\
\hline
\end{tabular}


Table 2. Average price of housing units (4.5 rooms) in certified and non-certified buildings sold in 2013

\begin{tabular}{llll}
\hline & $\begin{array}{l}\text { IS } 5281 \\
\text { homes }\end{array}$ & $\begin{array}{l}\text { Non-certified } \\
\text { homes }\end{array}$ & Difference \\
\hline Average apartment price (NIS) & $1,855,000$ & $1,600,000$ & 255,000 \\
Average apartment size $\left(\mathrm{m}^{2}\right)$ & 117 & 120 & -3 \\
Average price per unit floor area & 15,793 & 13,642 & 2,151 \\
$\left(\mathrm{NIS} / \mathrm{m}^{2}\right)$ & & & \\
\hline
\end{tabular}

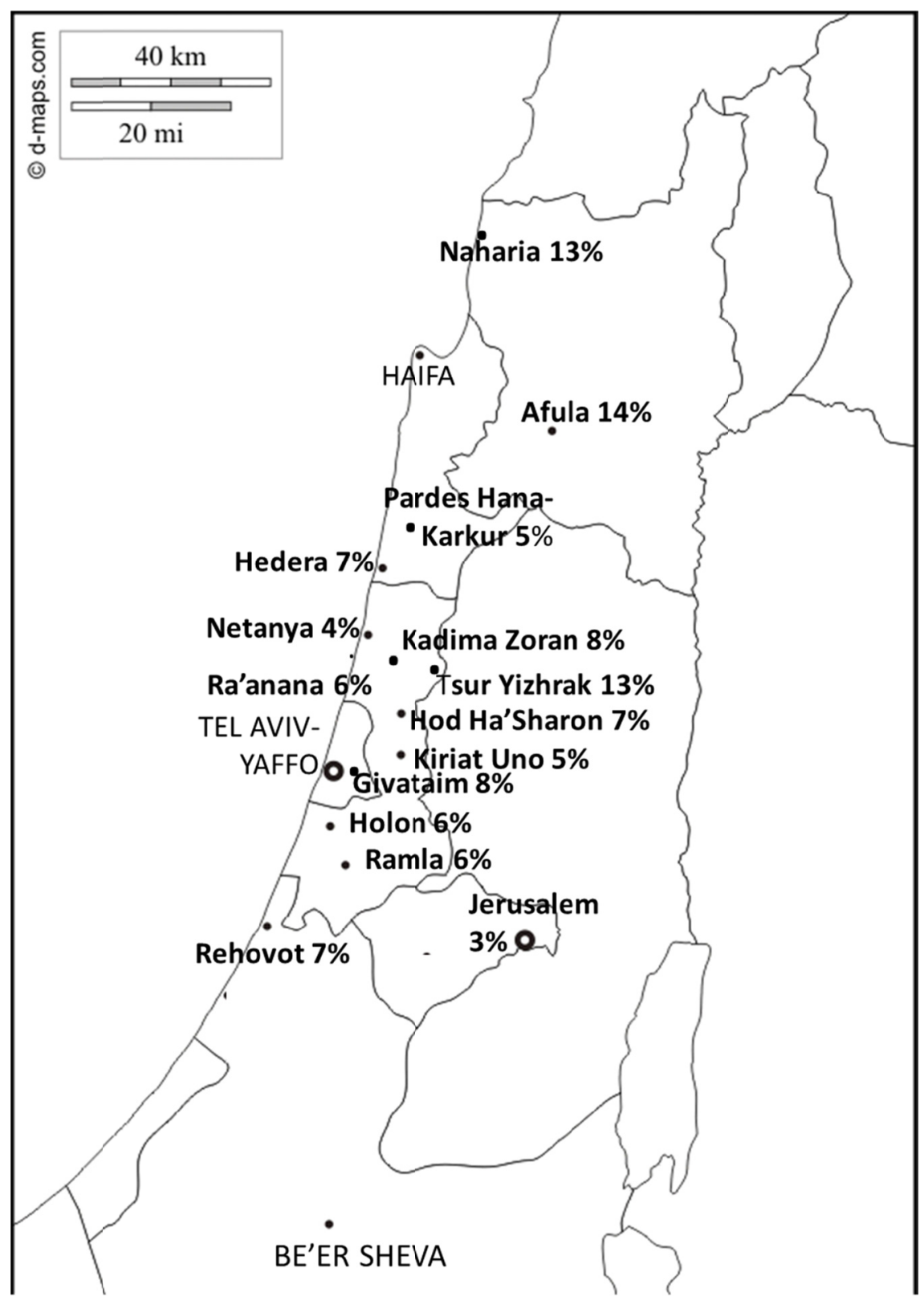

Figure 2. The 'green' premium in Israel

Source: Own data, 2016; Map: Machline, 2017 
Table 3. The 'green' premium in Israel. Source: Own data, 2016

\begin{tabular}{ll}
\hline City & 'Green' premium (\%) \\
\hline Be'er Yaakov & 7 \\
Givataim & 8 \\
Hod Ha'sharon & 7 \\
Hedera & 7 \\
Holon & 6 \\
Jerusalem & 3 \\
Pardes Hana-Karkur & 5 \\
Naharia & 13 \\
Netanya & 4 \\
Zur Yizhak & 13 \\
Kadima Zoran & 8 \\
Kiriat Ono & 5 \\
Rehovot & 7 \\
Ramla & 4 \\
Ra'anana & 6 \\
Afula & 14 \\
Average & 7.3 \\
\hline
\end{tabular}

In this sample, the' green' premium ranges between $3 \%$ and $14 \%$ depending on the city (see calculation details in the Annex). It is highest in the Northern periphery (13\%) and the average is $7.3 \%$. In the U.S., we can see slightly higher average values: for example, Khan and Kok (2012) found a green premium of $9 \%$ in California, and according to Kaufman (2010) the premium in Seattle is $9.1 \%$. Thus, despite the wide range of values, the average "green" premium in Israel is just slightly below those observed in the U.S.

The 'green' premium is smaller in the center of the country, where most construction takes place. This is because around the Tel Aviv metropolitan area (including the central and Jerusalem districts), housing prices are high regardless of 'green' certification, and in fact the 'green' premium embodies a minimal difference in actual construction costs - given the negligible difference in requirements (Goulden, 2015) between SI 5281 at a one star level (Note 2), and the mandatory standard SI 1045, in the climate of the mild coastal region.

Based on these results we can estimate the added profitability of green building for developers, by comparing the 'green' premium that the homebuyer will pay with the extra building costs for the developer. According to Kot and Katz (2013), the additional costs of 'green' building construction for new apartments range between $2.1 \%$ and $4.1 \%$. However according to the Israeli Builders Association (2015), actual building construction typically represents only $35 \%$ of the total project cost (which also includes the costs of land, infrastructure development, design fees, taxes, etc. which are not likely to vary significantly due to the building's 'green' design, certification and construction). This means that the average 'green' premium of some $7 \%$ that a homebuyer will pay for a new apartment is considerably higher than the percentage added cost to the developer - which is in fact marginal in the scope of the overall project cost (around 1\%). If, as stated by the Israeli Builders Association (2015), the average profit for a conventional apartment sale is $12.7 \%$ of the housing unit price, the profit for a 'green' apartment is likely to be in the range of $15-25 \%$.

Given the 'green' premium we found, we estimated the payback time for the consumer to recoup the additional investment through water and electricity savings. According to the Israeli Ministry of Environment Protection, 'Green building may save about $15 \%$ of electricity consumption and $10 \%$ of water demand for a household (Note 3 ). An average Israeli household consumes $7,800 \mathrm{kWh}$ of electricity per year, and the average electricity price is $0.6 \mathrm{NIS} / \mathrm{kWh}$ (Israeli Electricity Company, 2014). As a rough estimate, thanks to 'green' building an Israeli household can save some $1,150 \mathrm{kWh}$, worth close to 700 NIS per year. An average Israeli household also consumes about 180 cubic meters of water per year, at an average price of about 14 NIS per cubic meter (Note 4). Thus 'green' building can save some 18 cubic meters, or around 250 NIS, per year. In sum, an average Israeli 
household can foresee saving close to 1,000 NIS (about \$250) per year thanks to these monetarily tangible aspects of 'green' building.

The average price for a 'green' apartment in our sample is 1,850,000 NIS. Even at the low end of the 'green' premium range, the additional cost of $3 \%$ paid by the homebuyer for 'green' certification is in excess of 50,000 NIS, which is unlikely to be recouped within the period of that buyer's apartment tenure. Thus, it is not profitable to purchase a 'green' apartment for its energy and water saving potential. If, however, developers were only charging consumers for added construction costs (about 1\% of the apartment price), the 'green' premium investment could more realistically be recovered.

The benefits of 'green' building may also be estimated for the Israeli economy as a whole. According to Ariav and Amir (2011), the costs to society of air pollution due to power generation are 0.18 NIS per kWh of electricity generated, and the electrical consumption of desalinated water is $4 \mathrm{kWh}$ per cubic meter (Water Authority, 2009). So, given the average annual consumption of water and electricity, a household purchasing a green apartment "saves" the national economy some 200-250 NIS/year in pollution costs, in addition to the savings (about 1,000 NIS) accruing directly to that household.

\subsection{Case study: A 'Green' Neighborhood in North Tel Aviv}

The neighborhood of Neve Sharett is located in northern Tel Aviv (see Figure 1). Originally it was a transit camp, founded in the 1950s to house immigrants who had arrived primarily from North Africa. In the 1960's the state built social housing units to replace the transit camps, and public housing tenants have mostly purchased their own homes since the late-1990s (due to the 'Ran Cohen' law (Note 5) of 1998).

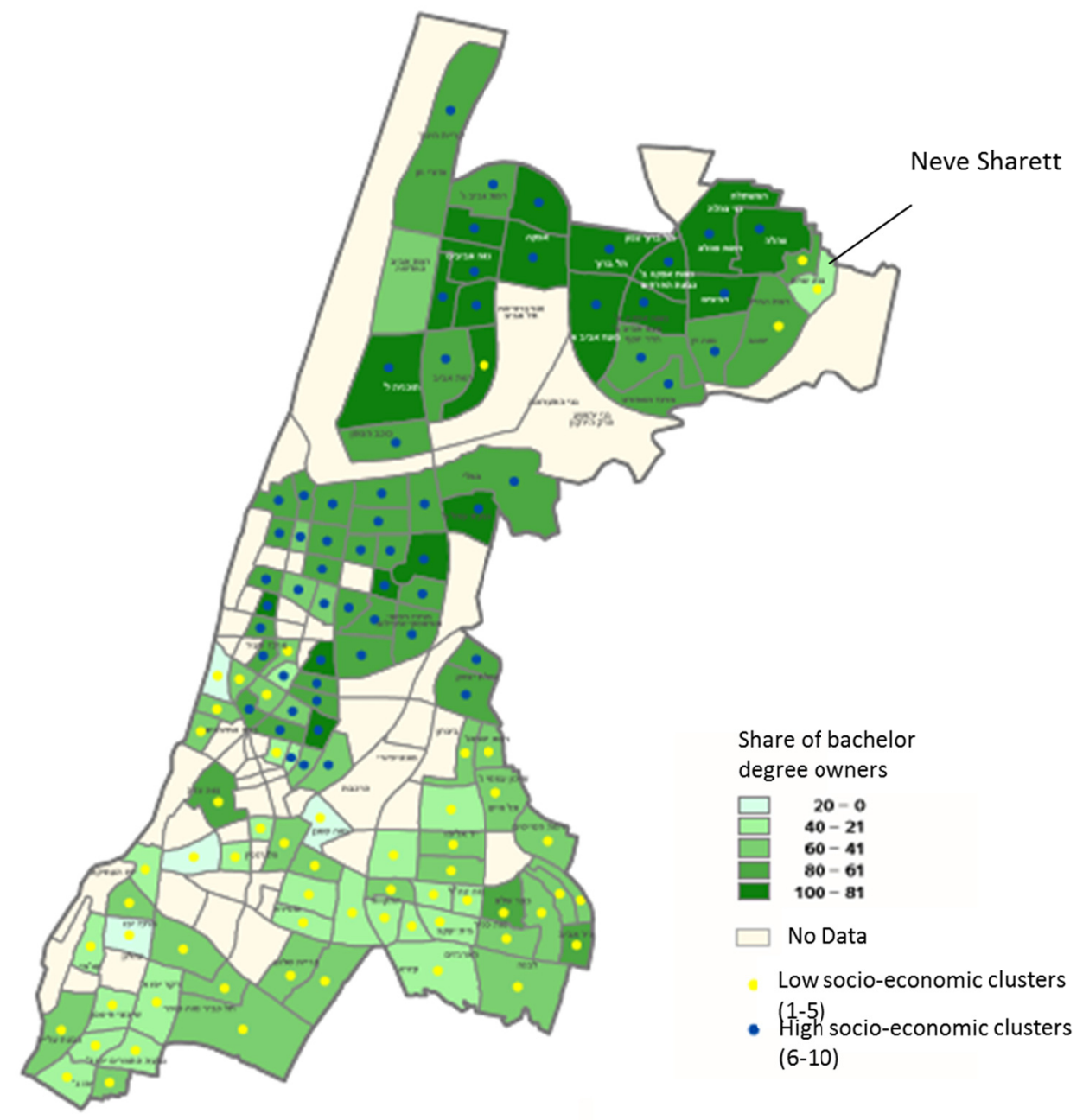

Figure 3. Map of Tel Aviv census tracts showing the distribution of population in terms of socio-economic indicators (share of population with higher education, and socio-economic clusters)

Source: Israeli Central Bureau of Statistics, 2008 


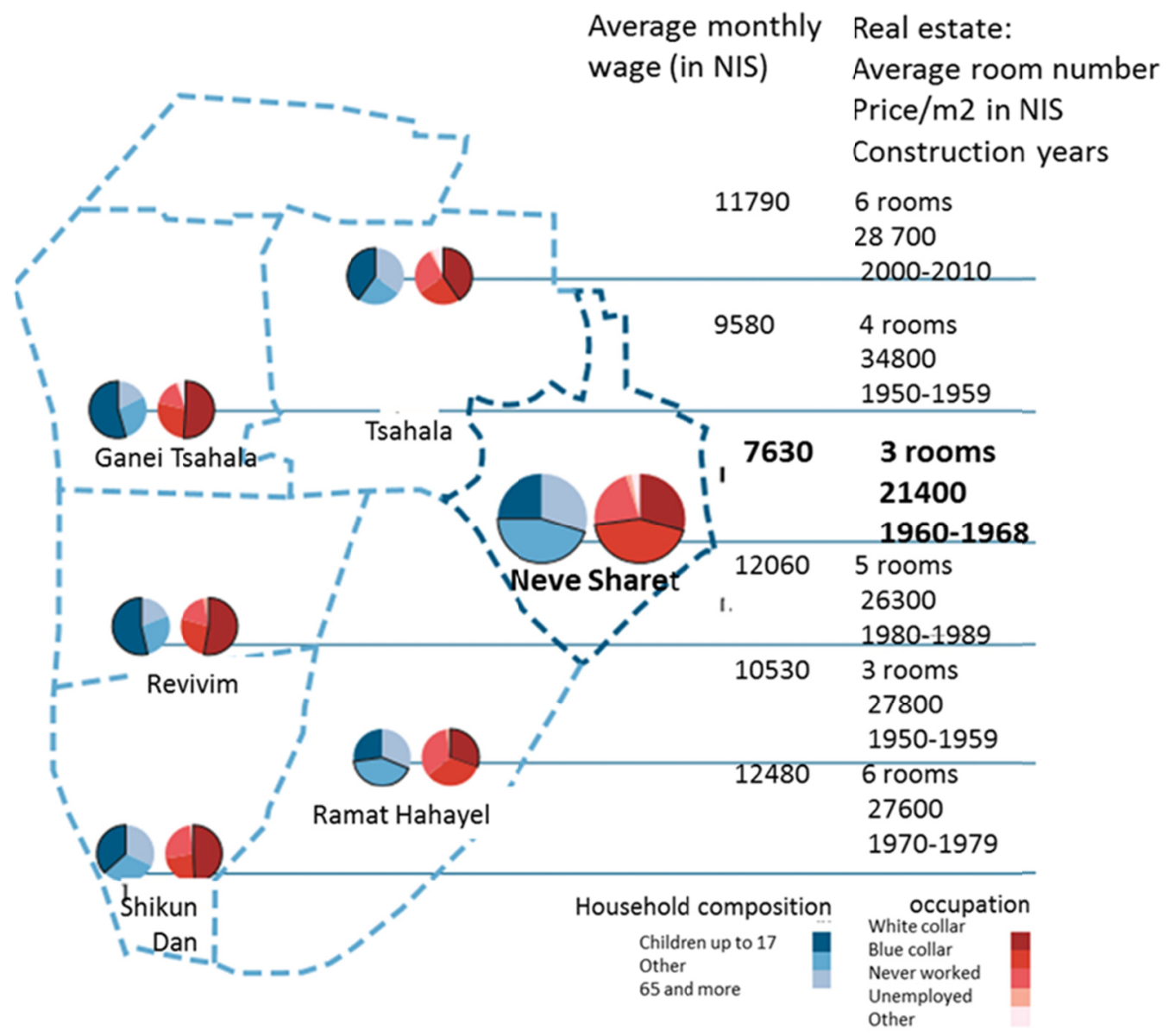

Figure 4. Socio-economic data for Neve Sharett and surrounding neighborhoods

Source: CBS, 2008; Tel Aviv municipality, 2013

Today, (before gentrification) Neve Sharett is a residential neighborhood and includes a high-tech center. It stands in stark contrast to the wealthier neighborhoods adjacent to it in north Tel Aviv, and still maintains relatively cheap housing - a disappearing commodity in most of the city. According to the socio-economic data in Figures 3 and 4, we can see that in Neve Sharett the share of the population holding bachelor's degrees and employed in white collar jobs is very low compared to the rest of northern Tel Aviv, and that the population falls into low socio-economic clusters (between 1 and 5).

In 2003, the Ministry of Housing declared that the neighborhood is eligible for a vast renewal program. Urban renewal in Israel generates new construction in pre-existing built-up areas, a solution which the government adopted in response to the scarcity of land for new construction and the subsequent housing shortage.

There are two main schemes for urban renewal projects. The first is known as 'pinui-binui' (evacuation and reconstruction), and the second is an outcome of the national plan to strengthen older structures, known as TAMA 38. Neve Sharett was declared eligible for pinui-binui.

Evacuation and reconstruction projects rely on the 2002 Planning and Building Law. Under the law, a specific urban area is declared an area of evacuation for reconstruction - existing buildings may be replaced by new construction, with significantly enhanced building rights (several times greater than the existing rights), while demanding more green areas. The national Pinui-Binui project offers planning grants and tax waivers to developers willing to take the risks, to assist with obtaining owner approval, rehousing during the construction period and construction costs. To encourage evacuation and reconstruction, existing homeowners enjoy public grants and tax benefits such as exemption from capital gains tax, purchase tax, VAT on construction services, permit fees, improvement levies, and discounts on municipal taxes in their new apartments.

Typically, the areas declared as sites of evacuation and reconstruction are considered under-populated; they often 
have outdated infrastructures and face significant socio-economic challenges (as is the case in Neve Sharett). When the renewal process is initiated, residents are notified that they live in an area designated for evacuation and reconstruction. Homeowners with an understanding of the issues at hand may rally together and initiate meetings with developers, to either advance the project or prevent it. In some cases, a developer informed that a specific site has the potential to undergo evacuation and reconstruction will approach the residents and attempt to convince them to sign up for the re-construction project. The scheme requires the signed agreement of $80 \%$ of the local residents (i.e. apartment owners). In 2006, a reform in the evacuation and reconstruction Act was introduced, stipulating that residents refusing to accept the offer of evacuation and reconstruction without any clear or reasonable explanation are responsible for damages caused to other residents in the building due to a delay or cancellation of the project. (Note 6)

Neve Sharett has been divided into a several evacuation and reconstruction projects. We focus here on one of them, the 'Green Park' project, in which the buildings were certified by a private institute rather than the SII itself (SI 5281, at the base level of one star).

The Green Park project was initiated in 2006, when the local residents hired professional consultants (an architect and a lawyer) to defend their rights and establish a master plan for their neighborhood under an evacuation and reconstruction framework. The neighborhood's 154 households (as of 2013) included 62 private rental tenants, 16 public social housing tenants and 76 owner residents.

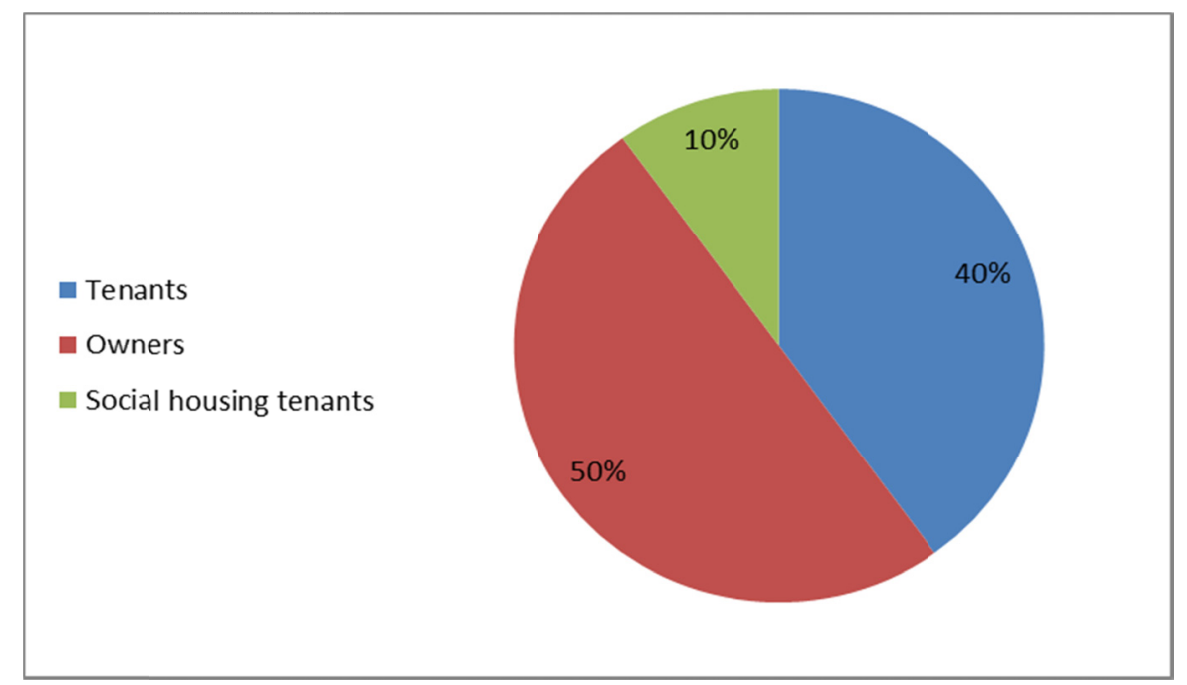

Figure 5. Residents' categories before evacuation in 2013

Source: Original survey data, 2017

The consultants declared that they work with a "social model" through the following steps:

1) The apartment owners contact the consulting firm.

2) The firm collects information on the objectives of the owners (including the social housing company Amidar, which owns 16 of the apartments).

3) The consultants establish a master plan for the municipality.

4) When the master plan is approved, the consulting firm publishes a call for tender to find a developer (stipulating that construction will be according the SI 5281 standard).

5) The developer must get the apartment owners' agreement to start the evacuation and reconstruction project (Consulting firm, 2017).

The Green Park master plan was accepted by the Tel Aviv municipality in 2013, and three developers were selected to implement it. According to the consulting firm (personal communication, 2017), the residents wished to include the SI 5281 certification, as they wanted to live in a 'green' neighborhood - although the residents' association representative was unaware that the new apartments were built according to that standard, and simply 'wanted the best building quality standards' (personal communication, 2017). Thus, one of the requirements published in the call for tenders was to build according to SI 5281 - even though 
when the plan was accepted, the standard had not yet been adopted as mandatory in Tel Aviv and in the other Forum 15 cities. According to the consulting firm (personal communication, 2017), potential developers were not disturbed by the clause, which is similar to the mandatory SI 1045 standard. According to the arrangements described above, the scheme required the signed agreement of the current apartment owners. The residents lived for decades in ten linear buildings (binyanei rakevet (Note 7)), with a total of 154 fifty-year old apartments. Under the evacuation and reconstruction scheme, the ten buildings were demolished in 2014 and six towers, with between 10 and 26 stories and containing a total of 447 apartments, replaced them. The floor area of the new apartments is 120 square meters on average, but $20 \%$ are 'small' apartments of 90 sq.m. The occupants (owners and Amidar social housing tenants) were moved to similar rental apartments funded by the developers in close vicinity of their homes. The project developers managed to get planning permission to build three new apartments for each existing one.

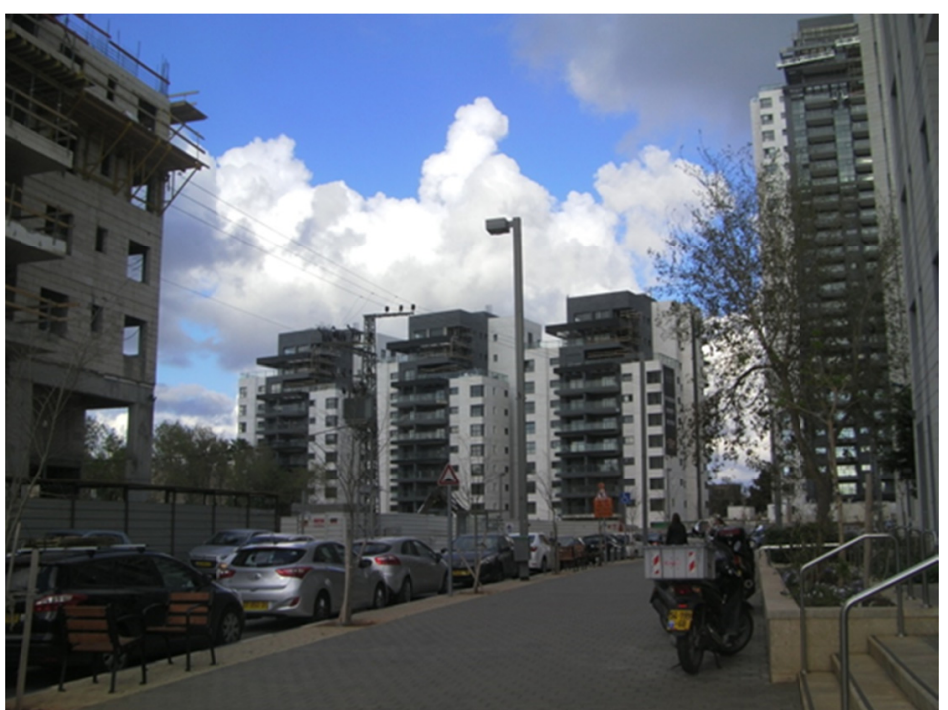

Figure 6. View of the site following completion of the project, known as "Green Park" due to its 'green' certification (SI 5281). Photo: Machline, 2016

\subsubsection{Results}

\section{Economic impacts results}

1) For the individuals

Each owner received a brand new, 4.5 room apartment (120 sq.m. on average). All apartments include modern kitchens and bathrooms, a balcony and two covered parking spaces. Each new building showcases a luxurious lobby, a state-of-the-art elevator, and manicured gardens. The market price of these new apartments is at least 2.3 million shekels (whereas existing units, prior to the renewal, were valued on average at 1.1 million shekels).

2) For the developers and the consultants

Following the redevelopment process, the developers' investment yielded 293 new apartments to sell on the free market at full price, while another 154 units were allocated to former apartment owners.

The lawyer for the consulting firm that drew up the master plan received a commission equal to $1.5 \%$ of total apartment sale revenues, higher than typical commissions which are currently between $0.75 \%$ and $1 \%$ ('Calcalist', 2016). The architect who designed the project received 10,000 NIS per apartment and another 40 NIS/sq.m. for underground space, 200 NIS/sq.m. for commercial buildings and 400,000 NIS when the master plan was accepted. Hence the architect received total compensation of about 17,000 NIS per apartment, as compared with about 4,500-6,000 NIS usually paid for such work ('Calcalist', 2016). The consulting firm in charge of collecting the agreements of residents (owners) received a commission equal to $3.5 \%$ of sales revenue. Considering that apartments were sold for 2.5 million NIS on average, this commission amounts to about 25.6 million NIS ('Calcalist' 2016). By July 2017, all of the apartments marketed as 'green' had been sold (for prices between 2.2 and 4.5 million NIS).

Social impact results

1) Population displacement and social crisis 


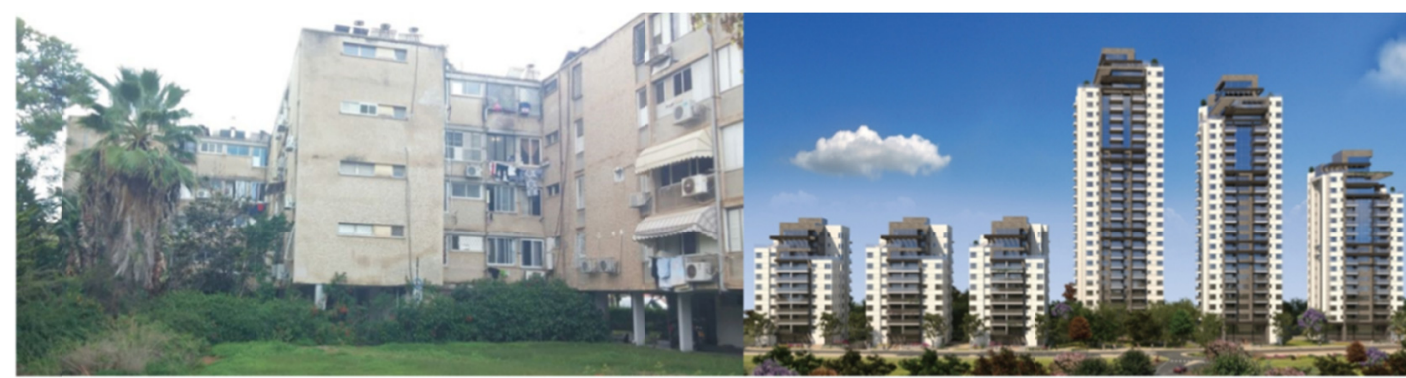

2008: 400000 NIS

2016: 2500000 NIS

Figure 7. Green Park neighborhood: 'social model' or 'greentrification'?

Source: Tel Aviv municipality/Developer website

All (non-social housing) tenants who were renting an apartment in the neighborhood by 2013 (40\% of the residents) had to leave by the end of their contract, and none purchased an apartment in the new project or could afford to rent in the renewed neighborhood (residents' union/social worker, personal communication 2017). According to the municipality social worker (personal communication, 2017), those who were renting an apartment in Neve Sharett will be displaced, and "due to gentrification and rising real estate prices, will find no apartment in the neighborhood, nor in the rest of Tel Aviv, and will thus have to leave the city".

Among the $60 \%$ of the existing residents entitled to receive an apartment (in other words: the residents-owners and public social housing residents) in the new project, the following survey done in March 2017 aimed to find out whether they plan to live in 'Green Park':

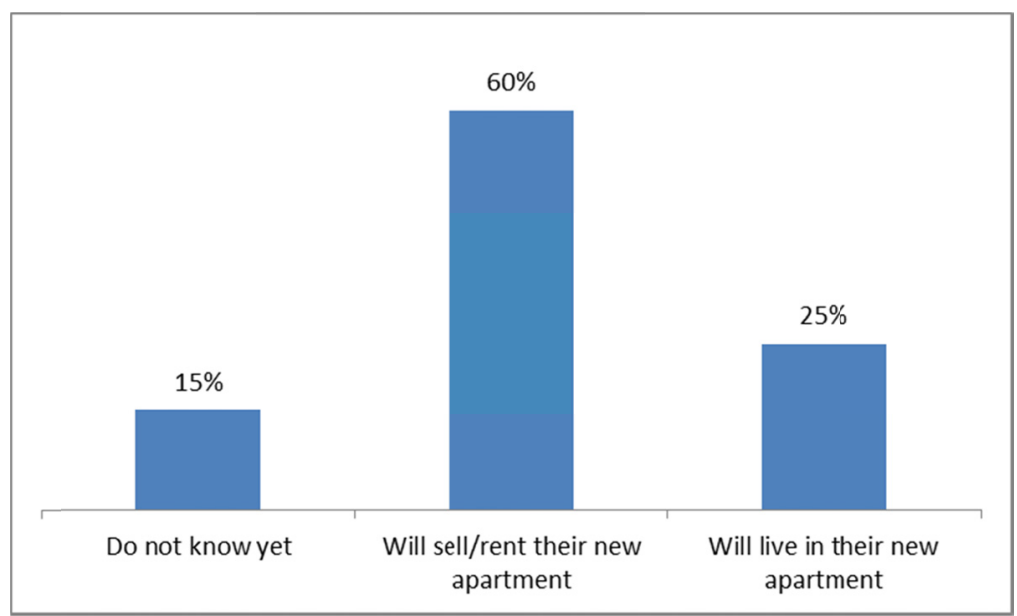

Figure 8. Resident's intentions regarding the new apartments

Source: Original survey data, 2017.

According to the survey, only $25 \%$ of the residents that will receive a new apartment will actually live in the neighborhood following the evacuation and reconstruction project. Thus, the 'Green Park' project of Neve Sharett is clearly leading to population displacement - symptomatic of urban gentrification. At the same time, the process of evacuation and reconstruction offered existing apartment owners "not living in Neve Sharett, because of its bad shape and reputation, the opportunity to return to a newly refurbished neighborhood" (Residents' Association representative, 2017).

The decision of apartment owners (70\%) who responded that they intend to sell or rent out their new apartment could be attributed to a simple preference to live elsewhere, but in some cases reflects their inability to afford the new monthly bills: the maintenance charge will grow to 500 NIS (or 100 Euros) (previously 50 NIS-10 Euros), while the bi-monthly municipal taxes will rise to 1200 NIS (compared to 300 NIS on average previously). To assist residents with this new tax burden, the consulting firm has negotiated with the municipality a temporary discount 
of $30 \%$ during the three first years and $20 \%$ for the following two years, but after five years the discount expires.

Some residents reported that they signed the agreement even though their income was not high enough to afford the new monthly payments (Residents' Association representative, 2017). On the other end of the spectrum, residents refusing to sign the agreement had to face 'terrible social pressures' until they signed. One refuser was sued by neighbors in 2013 (under the 'objector resident' act framework). The court ordered him to sign within 60 days and after that delay to pay 908,000 NIS to compensate the neighbors. The developers also reportedly had a 'secret agreement' with a resident who received 3,000 NIS for each household he persuaded to sign (Residents' Association representative, 2017).

Regarding the public social housing tenants' group, the company had no official information on their relocation in the 'Green Park' project or elsewhere since they left their public social housing in 2014. As social housing tenants they were paying only 300 NIS (about \$80) per month for a $65 \mathrm{~m}^{2}$ apartment and less than 100 NIS in bi-monthly municipal taxes. They were supposed to enter the new apartments, and still did not know how much extra rent they would pay (for their larger apartments), neither for monthly building maintenance (nominally 500 NIS/month) nor for municipality taxes (since they would have a discount on the 1200 NIS basis and not 300 NIS as previously). The electric bills were also expected to rise due to the larger apartment size, and to the lack of solar water heating systems (in buildings of eight stories and above). However, in 2016 'the urban renewal authorities' (Note 8) (under the planning authorities' supervision) adopted a law aiming to defend the rights of public social housing tenants. According to this law, the difference between the previous and future monthly payments is to be subsidized by the project's developers, so that the tenant will still pay the same amount. In addition, the tenants must be relocated in the new project and the rents cannot be raised. However, it is not stipulated for how long this provision would be in force. Meanwhile, the tenants had no official data from the social housing company on their future conditions.

\section{Discussion}

\subsection{The Economic Impact of 'Green' Building in Israel: Prices and Profits}

One way of defining the 'green' premium is that it represents the added value of a real estate asset due its greening, i.e. because of its energetic/environmental benefits or to added prestige. However, Israel's housing market suffers from excess demand (Dovman, Ribon and Yakhin, 2012), and therefore we cannot assume that every buyer of a 'green' apartment selected it over an equally available conventional apartment for its 'greenness' - but rather as part of a decision-making process involving numerous variables (including location, size, etc. as well as price).

In Israel, 'green' apartments are mainly located in high socio-economic cluster municipalities (see Fig. 9). Three quarters of the SI 5281 apartments are located in socio-economic cluster localities of 6 and above, while the populations in the three lowest clusters have no access to 'green' housing opportunities. Most SI 5281 apartments are in the center of Israel, where housing prices are highest. Thus, 'green' building is mainly raising the price of real estate in locations where it is already expensive.

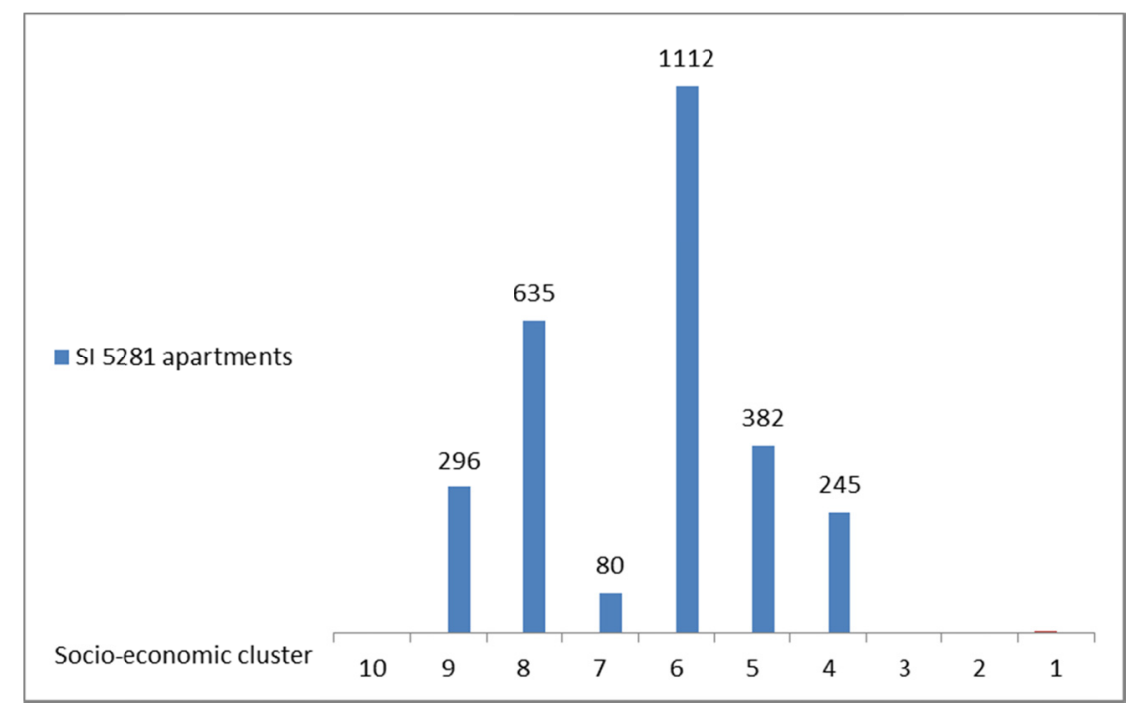

Figure 9. Certified 'green' apartments by socio-economic cluster (2012-2014)

Source: Ministry of Environmental Protection, 2016; CBS, 2008 
We may ask who profits from 'green' building, starting with construction companies and developers. According to the Israeli Builders Association (Note 10) (2015), actual building construction represents on average 35\% of a residential project's total cost. Furthermore, according to Kot and Katz (2013), the added 'green' building construction costs for new apartments are between $2.1 \%$ and $4.1 \%$. Considering an average value $(3.1 \%)$, added 'green' building costs represent about $1 \%$ of total project costs. This is much less than the $7.3 \%$ 'green' premium that a homebuyer is likely to pay, as mentioned. Even allowing for uncertainty and variation between parts of the country, the evidence suggests that developers are making a significant added profit on green apartments, which represents the bulk of the 'green' premium paid by homebuyers.

Still, many builders are unwilling to incur the trouble involved in applying for the standard - though in the Forum 15 municipalities, where it is gradually becoming mandatory they will have no choice. In order to ease the certification process, some municipalities like Tel Aviv have decided to pursue certification through a private Institute rather than obtaining the certification from the Israeli Standards Institute (SII). According to the SII consultant in charge of the SI 5281 development (personal communication, 2017), most municipalities belonging to Forum 15 obtain the standard from a private institute: "Since the standard is mandatory, and they are under pressure from the building companies, these authorities have had to find a way to ease the process. When a private institute started to deliver the 5281 standard (in 2013), it charged half price to developers (compared to the SII fee). Second, the final step of certification (in which a public committee attributes the 'green' label) may take months; to avoid completion delays, the private institute skips that process and attributes only a certificate of SI 5281 compliance and not the 'green' label (which only the SII has authority to confer)."

The average price of a 'green' apartment in our sample is 1,850,000 NIS, and assuming the average 'green' price premium of $7.3 \%$, the added expense incurred by the homebuyer is some 135,000 NIS. While this illustrative calculation embodies multiple uncertainties and variations - it shows that the time period required for a homebuyer to repay the investment in a 'green' apartment is likely to be over 100 years. Thus, the energy and water savings potential of a 'green' apartment does not even come close to justifying its purchase.

However, the purchase of a 'green' apartment may very well be justified by its resale value. Studies in the U.S. have examined certified 'green' apartment resale values and shown that in Seattle, for example, "green apartment" prices were higher by about $9 \%$ and were sold four times faster than non-certified homes (Kaufman, 2010). Moreover, if developers were only charging consumers for their added construction expenses (about $1 \%$ of the total project cost) and considering that the standard developers' profit is $12.7 \%$ of the apartment price (Israel Builders association, 2015), the 'green' premium for the consumer would only be about 20,000 NIS. Under such conditions, energy and water savings alone would allow a household to repay its 'green' investment in some 20-25 years - a lengthy period, but still a relevant consideration for some homebuyers.

\subsection{Future prospects}

In the coming years, approximately 45,000 housing units per year are expected to be built to meet the needs of the Israeli population (National Economic Council, 2014). According to the above estimations, if they were all built according to the 'green' standard, the economy would avoid costs of about 50 million NIS/year (about 13 million \$/year). However, if we take into consideration that the national budget was 360 billion NIS in 2016 (Israeli Ministry of Finance website, http://mof.gov.il/BudgetSite/statebudget, retrieved on the 28/01/18), it would represent an economy saving of only $0.01 \% / y e a r$, thus insignificant. Then most 'green' apartments were built according to the 'one star' level which is not more energy efficient than the mandatory insulation standard (1045) (Goulden, 2015). According to Garb et al (2015), SI 5281 is mainly implemented today at the lower levels of certification. While the standard is complex and ambitious, the requirements of the energy section for lower certification levels do not reflect a significant improvement over current practice in the market. Thus, the extra cost that homebuyers pay for 'green' apartments cannot be justified. However, for example in the U.S., a study done by Kats (2003) on 60 LEED rated buildings, demonstrates that 'green' buildings- when compared to conventional buildings- are on average $25-30 \%$ more energy efficient.

Even though this represents an extreme scenario, most building construction (as of 2017, about 67\%) is taking place in the Forum 15 municipalities - where the 'green' building standard has been adopted as mandatory for residential buildings (National Economic Council, 2017). It should also be noted that the housing offered in these cities may be more expensive, due to the 'green' premium.

According to Cohen et al. (2017), improved 'green' building that meets the more stringent requirements of 'two-star' and above ratings could significantly reduce energy consumption and greenhouse gas emissions, and could be incentivized effectively through State subsidies - and given the potential economic benefits estimated, such a policy would appear cost effective. 
In our Tel Aviv case study, we have seen that 'Green Park' is a residential development directed to the middle and upper middle classes. Evacuation and reconstruction is a national project to encourage more 'efficient' land use in urban areas, by replacing existing medium-density, multi-family residences with high-rise buildings that are designed to meet much higher standards.

Following the clearance and redevelopment of Neve Sharett (currently in the final stages of construction) in north Tel Aviv, 154 homes built in the 1960s as public housing will become 447 apartments in six towers (certified 'green'). The site had a high rate of private rentals, whether by initial tenants who became owners, or by investors who purchased the flats intending to redevelop. The program does not create nor preserve affordable housing. Thus, virtually all non-owner tenants ( $40 \%$ of the residents) had to leave the neighborhood when the evacuation and reconstruction project was launched. Among the owners, our survey indicates that $70 \%$ will be unable to stay in the 'green' neighborhood. In sum, the 'greening' of Neve Sharett has led to gentrification and population displacement.

At the same time, the urban renewal authorities' 2016 law aimed at preventing the public housing tenants from being moved out will technically allow this low-income population to live in upgraded apartment buildings for an affordable price. If these public dwelling tenants (16 households, or $10 \%$ of the total) are really resettled within 'Green Park', their housing units may be considered 'green' and affordable (though this scenario seems to be an unexpected and unintended project result, and as mentioned, is still uncertain).

\section{Conclusion}

We have examined the impact of green building prices on home buyers in Israel. Our analysis indicates that 'green' building tends to raise the price of green construction by at least $3 \%$ in the center of the country and by as much as $14 \%$ in the northern periphery, and that these 'green' housing sales premia are much larger than the additional cost of construction. They are also high relative to the economic value of their saving potential. Thus, we may also hypothesize that local authorities promote green building to 'brand' their cities as 'green', inducing gentrification, e.g. attracting higher-income residents.

These findings should be viewed within the context of Israel's surplus housing demand due to limited supply. This weakens the assumption that every 'green' apartment home buyer chooses to buy it for being 'green'. In fact, according to a survey initiated by the Israeli Green Building Council (ILGBC) in 2012 and published in 2013, 44\% of the interviewees had very poor knowledge of 'green' building (see Annex).

In terms of investment return, our analysis suggests that it is not "profitable" to buy 'green' apartments, but people are actually buying them. Due to the nature of the housing market, homebuyers tend to purchase an apartment that matches as closely as possible their primary requirements, in terms of location, price, size, environment, etc. and in many cases they cannot choose an equivalent apartment that is not 'green'. Thus the 'green' premium does not represent the price the home buyer is willing to pay for the apartment's greenness. According to the ILGBC survey (2013), $35 \%$ of the interviewees were willing to add up to 35,000 NIS for a 'green' apartment, $40 \%$ up to 25,000 NIS (the rest were unwilling for any extra-cost) less than the average premium in this study. That result shows that Israeli homebuyers are usually not interested in 'green' apartments. The 'green' value is lower than in the U.S. while the share of certified apartments is smaller.

'Green' building marginality in Israel may be explained by the fact that builders and construction companies make such large profits that it is not worth it to deal with the extra costs linked to administrative and monitoring fees and procedures. According to the Association of Contractors and Builders (2011), the new standards issued by the government of Israel over the last decade include harsher requirements such as disability-oriented modifications people; better fire safety, physical protection, and seismic resistance; façade covering; and thermal insulation. These modifications added some NIS 200,000 (about \$50,000) to the cost of each apartment. The 'green' value cannot be explained by a higher quality nor by energy saving. Meanwhile, in the U.S. where the 'green' premium is a bit higher, 'the 'green' standard involves an important energy saving. 'Green' building is used as a gentrification tool in well to do municipalities' neighborhoods not seen as attractive by themselves (for example due to proximity with the sea). However, usually even compliance with the mandatory insulation standard (1045) is not enforced, due to a lack of technical inspection (besides in some high standard estate projects of wealthy neighborhoods). Thus, the fact that the 'green' building standard involves an inspection and complies with the 1045 certification represents an improvement in terms of energy efficiency.

As of now (2018), there is no 'green' affordable housing to mitigate this phenomenon in Israel. The energy and water saving potential of a green apartment does not by itself justify its purchase. Moreover, the typical 'green premium' - in terms of the sale price of an apartment in a certified building - is significantly higher than the additional construction costs required to build it. 
We can conclude that currently there is no green and affordable housing in Israel, and no established 'green' neighborhoods evince significant social diversity. Certified 'green' homes are essentially unavailable to lower income populations, and absent from their neighborhoods. We have shown in our case study that 'green' building is being used as a gentrification tool, to attract middle class households to previously poor neighborhoods.

While in centrally located and economically strong municipalities green certification is becoming more widespread, in peripheral locations such certification is not implemented - and the 'green' label is mainly used to attract local residents who can afford housing upgrade. In the most attractive locations, where gentrification is already occurring with housing refurbishment, developers hardly need 'green' certification, and are attracting the well-to-do without it. In locations where apartment prices and developers' profits are relatively low, it is not profitable to comply with the standard due to the extra administrative and monitoring fees and procedures. Also, in the most attractive places the developers do not need to build 'green' to sell the apartments and make a very high profit. Thus, only in potentially 'gentrifying' locations like Neve Sharett it seems that a 'green' building standard is seen as an attractive asset for the middle class. Urban gentrification appears following the renovation of old well-located neighborhoods like Neve Tsedek in Tel Aviv. Gentrification can also be based on local assets (for example in Yafo-south Tel Aviv- due to proximity with the sea). However, 'Green' building is used as a gentrification tool in well to do municipalities' neighborhoods not seen as attractive by themselves.

\section{References}

Ariav, Y., \& Amir, M. (2011). Economic Analysis and Reexamination of Government Solar Energy Policy in Israel - Updated Status (in Hebrew).

Banzhaf, H. S., \& McCormick, E. (2007). Moving beyond cleanup: identifying the crucibles of environmental gentrification. Andrew Young School of Policy Studies Research Paper Series, Working Paper 07-29, May, Georgia State University, Atlanta, GA.

Berry, T. (2007). Towards a Green Building and Infrastructure Investment Fund: A Review of Challenges and Opportunities. Compass Resource Management: Vancouver, Canada.

Checker, M. (2011). Wiped Out by the "Greenwave": Environmental Gentrification and the Paradoxical Politics of Urban Sustainability. City \& Society, 23, 210-229. https://doi.org/10.1111/j.1548-744X.2011.01063.x

Fuerst, F., \& McAllister, P. (2011). Green noise or green value? Measuring the effects of environmental certification on office values. Real Estate Economics, 39(1), 45-69. https://doi.org/10.1111/j.1540-6229.2010.00286.x

Garb, Y., Pearlmutter, D., Erell, E., Becker, N., \& Goulden, S. (2015). Survey of green building incentives and their adaptation to Israel. The Chief Scientist, Israel Ministry of Environmental Protection (Hebrew). Retrieved from http://din-online.info/pdf/sv6.pdf

Goulden, S., Garb, Y., Erell, E., \& Pearlmutter, D. (2015). Green building standards as socio-technical actors in municipal environmental policy. Building Research and Information.

Kats, G. (2003). The Costs and Financial Benefits of Green Buildings-A Report to California's Sustainable Building Task Force. U.S. Green Building Council: Washington, DC.

Krueger, R., \& Agyeman, J. (2005). Sustainability schizophrenia or "actually existing sustainabilities?" toward a broader understanding of the politics and promise of local sustainability in the US. Geoforum, 36(4), 410-417. https://doi.org/10.1016/j.geoforum.2004.07.005

OECD - Health Policy and Data: Health Division Website. Retrieved from http://www.oecd.org/department/0,2688,en_2649_33929_1_1_1_1_1,00.html

\section{Notes}

Note 1. We did not include Yavne in the calculation of the average green premium (as no conventional buildings have built near the 'Green Yavne' development, which thus lacks a reference sub-sample), and similarly refrained from including in our sample the seven certified buildings of Ashkelon, as there are no new conventional apartment buildings nearby. We also removed from our sample the one residential building (in Hod Ha'sharon) that received the ' 2 star' level of green certification.

Note 2. The standard is divided into five quality levels, ranked from one star to five stars for the highest quality level. 
Note 3. Based on estimates of the inter-ministerial committee for setting a national goal for reducing greenhouse gas emissions (MoEP, 2015).

Note 4. Per capita water consumption (Water Authority, 2014); the average number of persons per household (Central Bureau of Statistics, 2014); water price (Water Authority, 2015).

Note 5. "Law of Public Housing", 16/03/1998, number $9 / 1242 / 14$, which allowed residents of houses supplied by the state to assume ownership on the house.

Note 6 . There must be $60 \%$ agreement to submit the project to the local authority, $80 \%$ to get the local committee agreement, and $100 \%$ to receive the building permit.

Note 7. "Binyanei rakevet," or row-house tenements, were designed at the initiative of government to deliver a cheap and fast housing solution in the 1950s and 60s in response to the large waves of immigration to Israel. The buildings are modular structures with two, three or four stories, and a typical distribution of two small apartments per floor served by each stairwell.

Note 8. Retrieved from website: http://www.knesset.gov.il/privatelaw/data/20/3/931_3_1.rtf Consulted in March 2017.

Note 9. In Israel, a socioeconomic index (SEI) was developed by the Central Bureau of Statistics (CBS) in the mid-1990s, on the basis of the 1995 Population and Housing Census data (Burck and Kababia 1996). It includes 14 variables grouped in five groups related to the socioeconomic makeup of the population of different localities, subject to data availability. The groups are: (1) demographic characteristics (dependency ratio, median age, percentage of families with four or more children); (2) education and schooling (percentage of the students studying for a bachelor's or higher degree, percentage eligible for a matriculation certificate); (3) standard of living (level of motorization, percentage of new motor vehicles, average income per capita); (4) labor force statistics (percentage of job seekers, percentage of salaried workers and self-employed persons earning up to minimum wage, percentage of salaried workers earning more than twice the average salary); (5) support/pension (percentage receiving unemployment benefits, percentage receiving income supplements; percentage receiving old age pensions with income supplements).

Note 10. Founded in 1949, the Israel Builders Association is the sole representative-organization of businesses in the residential, non-residential and infrastructure construction sector. The Association strives to promote the interests of contractors and builders in Israel, and to resolve professional issues. The Israel Builders Association claims over 2,000 members.

\section{Appendices}

To identify the non-certified buildings sample for comparison purposes, we used the GIS software Gov Map. In the Naharia example, building 1 received the SI 5281 certification, so we compare it to non-green buildings in lot 34 . We compared apartments sold the same year and built during the same period (i.e. after 2008).

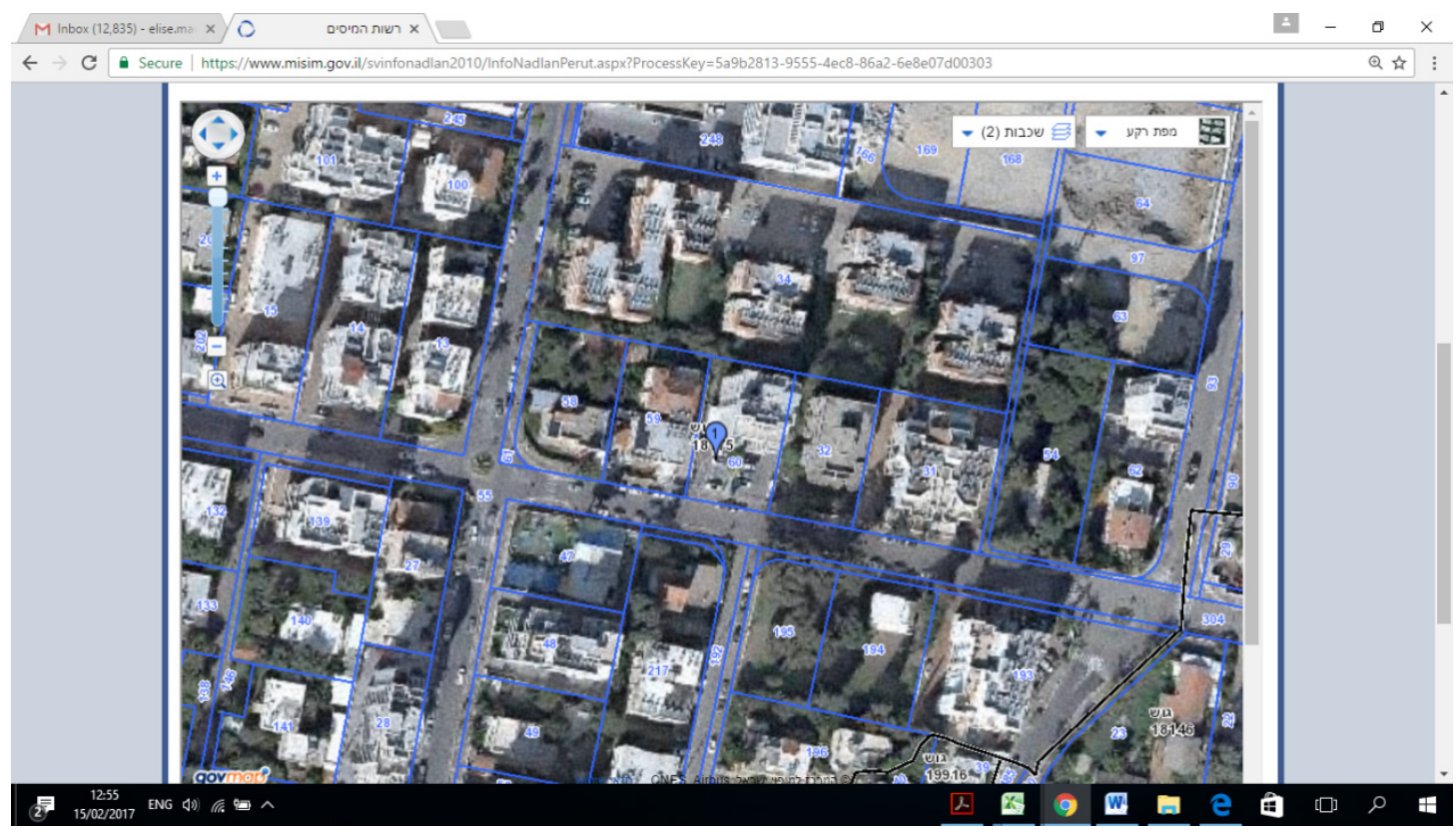


So we had the following sample:
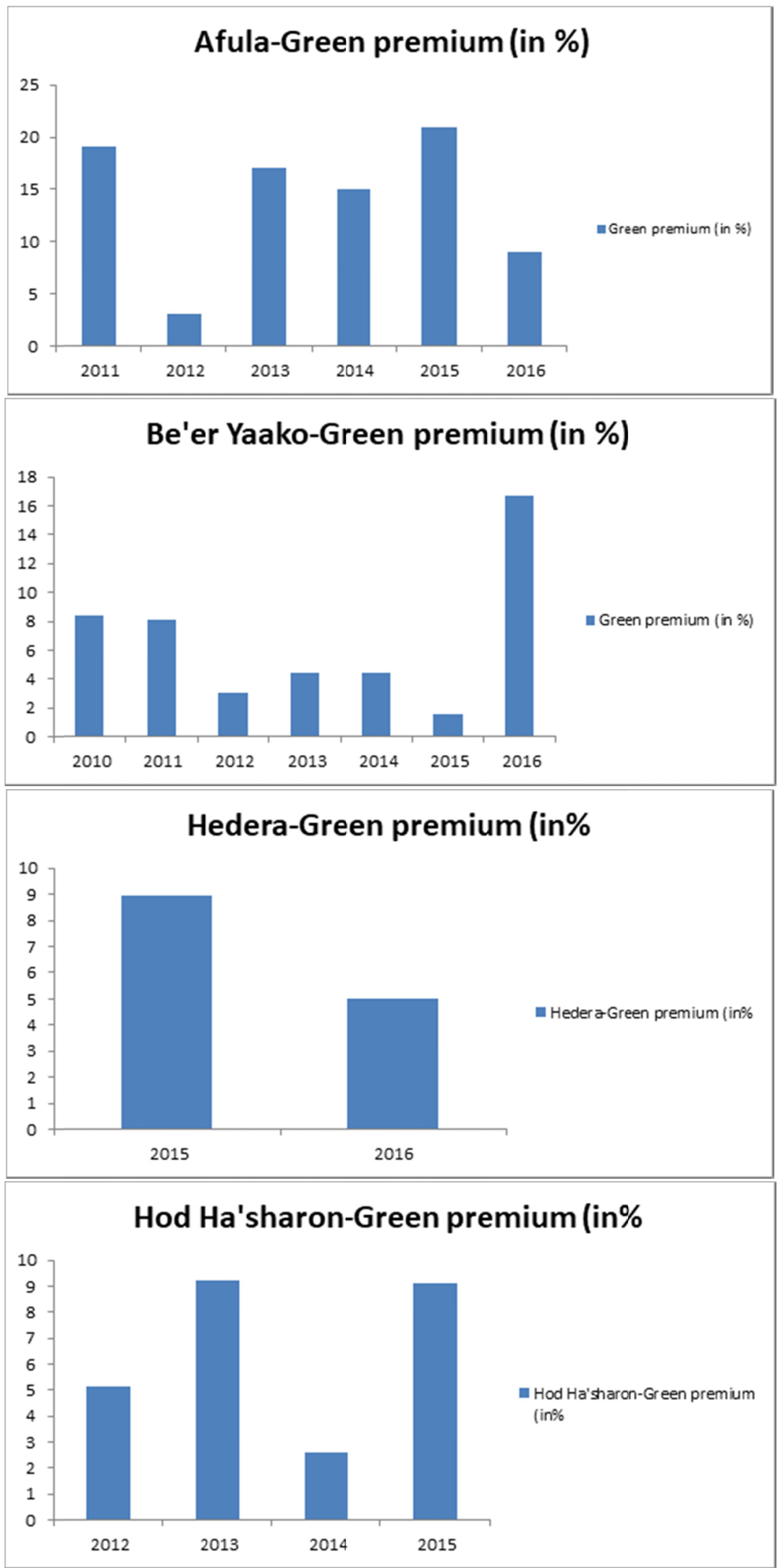


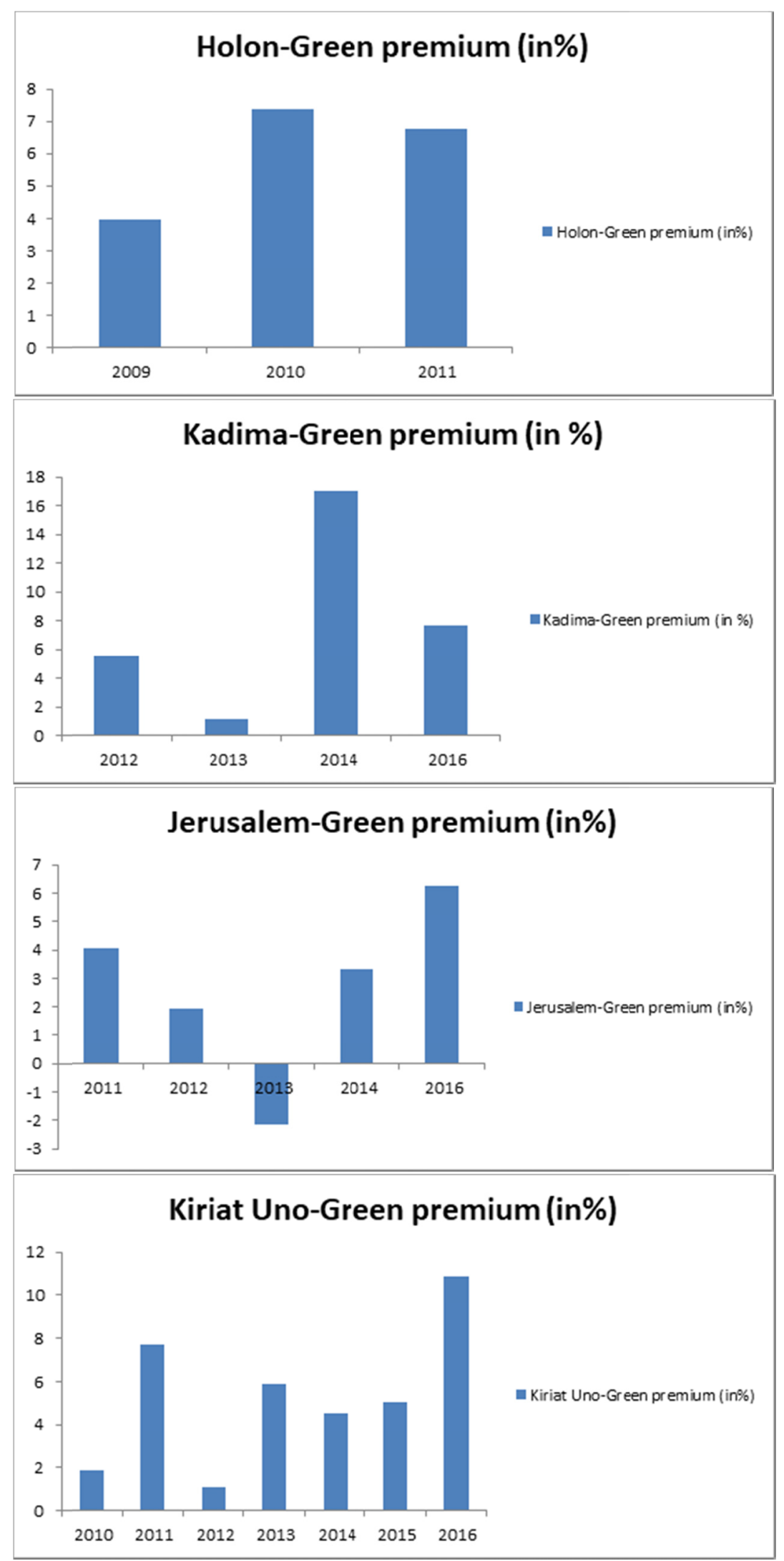




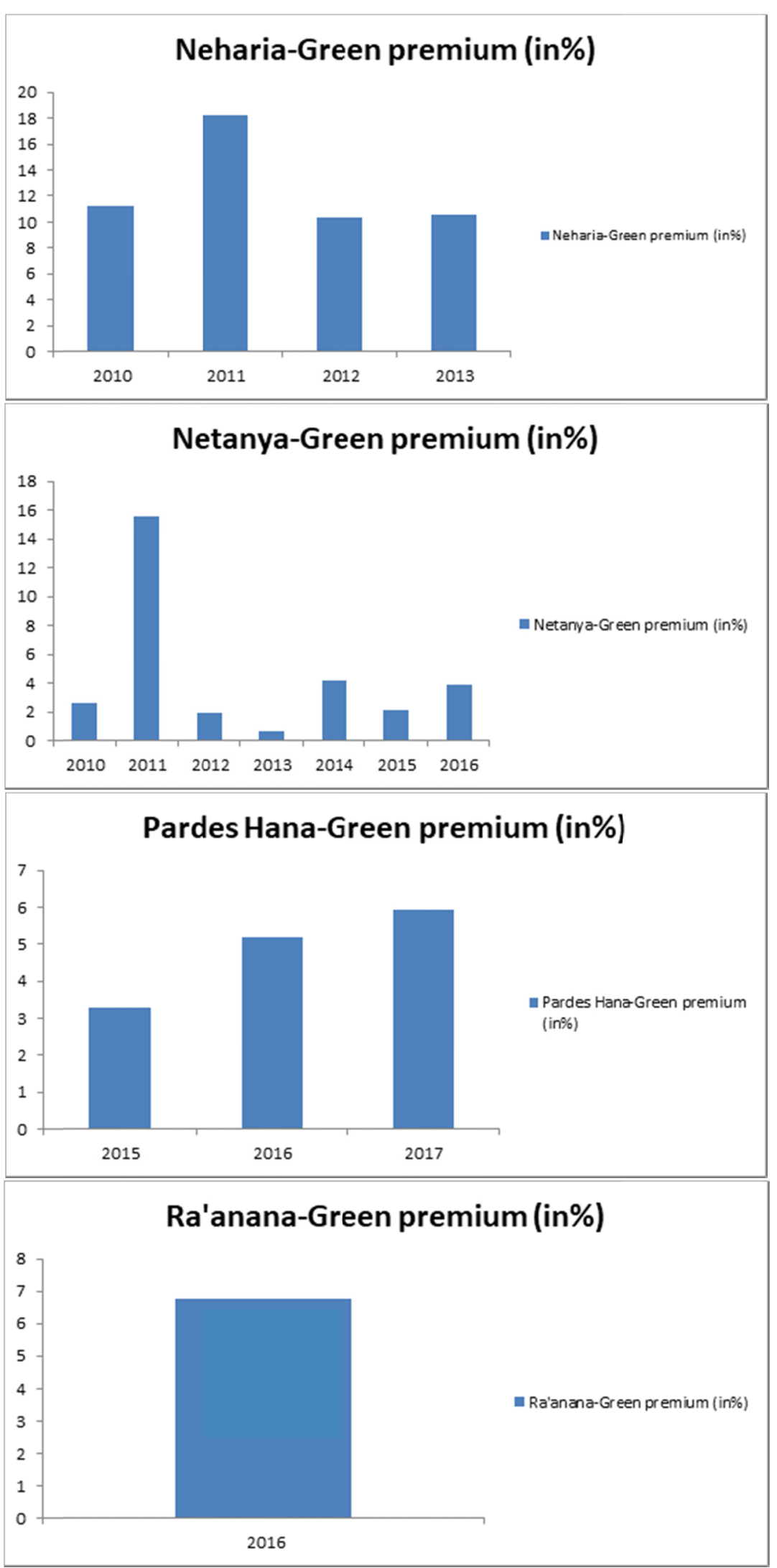



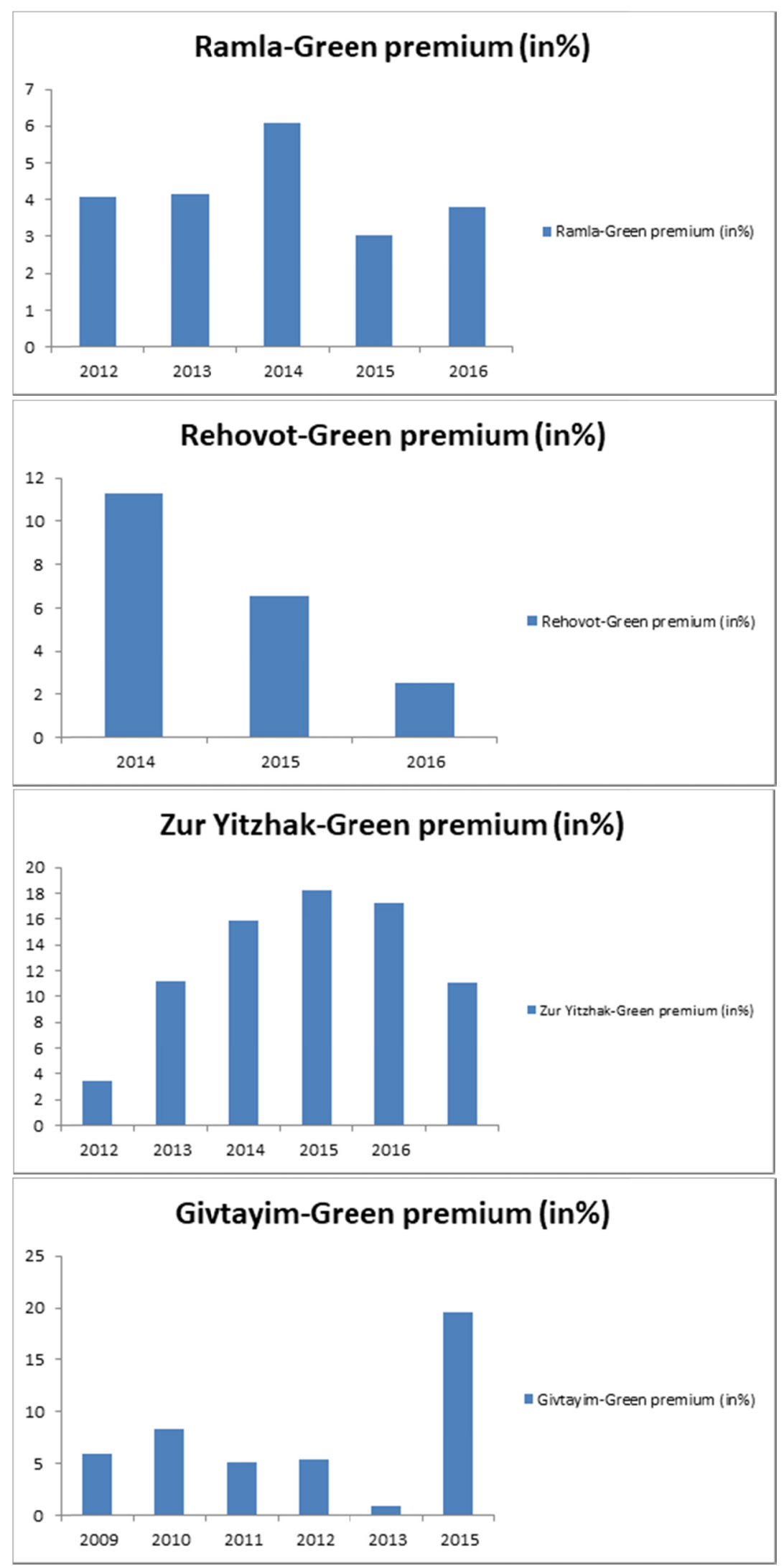

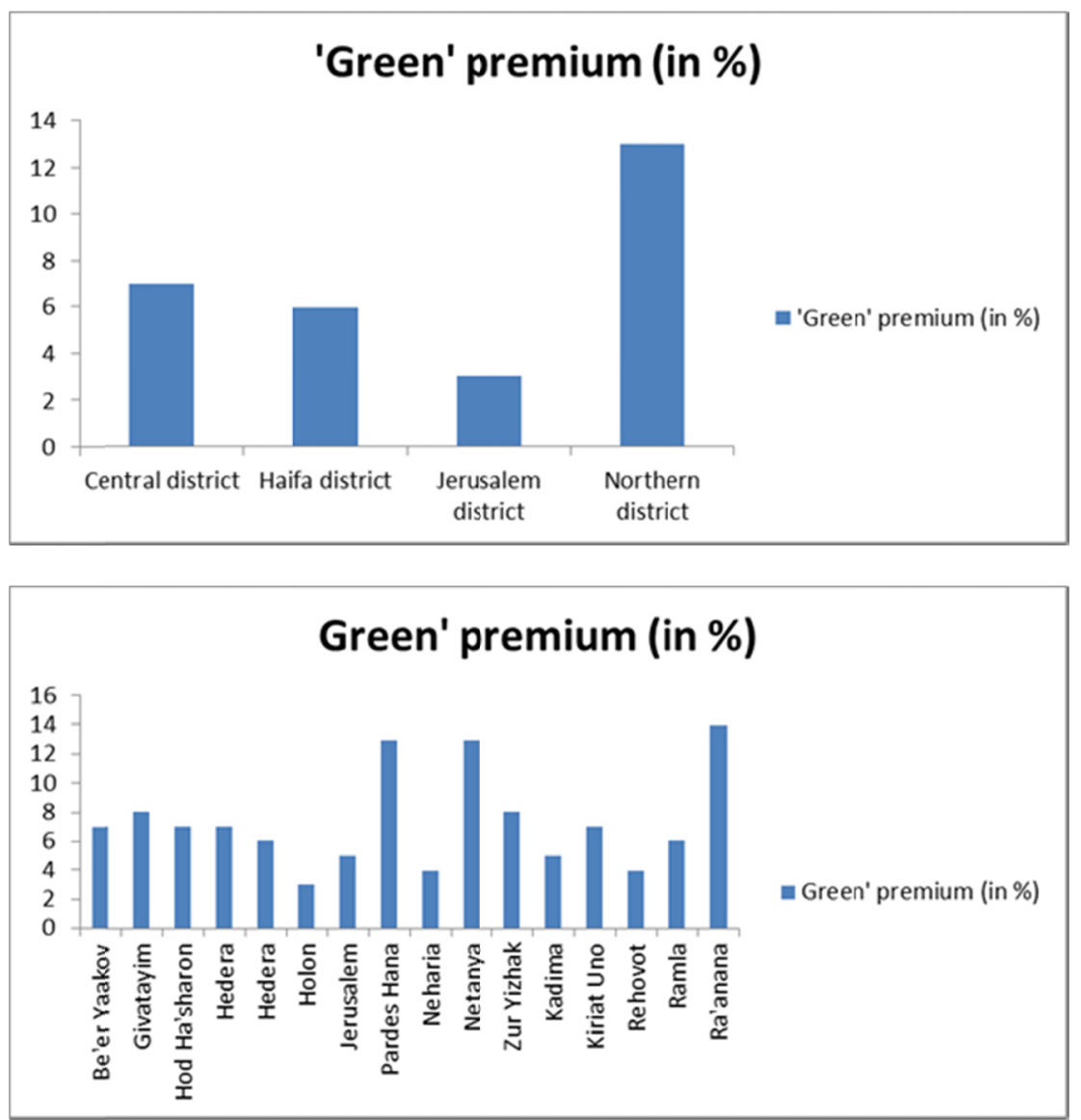

\section{Copyrights}

Copyright for this article is retained by the author(s), with first publication rights granted to the journal.

This is an open-access article distributed under the terms and conditions of the Creative Commons Attribution license (http://creativecommons.org/licenses/by/4.0/). 